\title{
STUDI PERBANDINGAN KEMAMPUAN Nannochloropsis sp. DAN Spirulina sp. SEBAGAI AGEN BIOREMEDIASI TERHADAP LOGAM BERAT TIMBAL (Pb)
}

\section{COMPARATIVE STUDY OF ABILITY Nannochloropsis sp. AND Spirulina sp. AS AGENT BIOREMEDIATION OF HEAVY METAL PLUMBUM (PB)}

\author{
Endang Dewi Masithah, Boedi Setya Rahardja dan Tri Nadya Olyvia Kerin Hardianie
}

Fakultas Perikanan dan Kelautan Universitas Airlangga

Kampus C Mulyorejo - Surabaya, 60115 Telp. 031-5911451

\begin{abstract}
Sea water is a component that interacts with the terrestrial environment, where the discharge of waste empties into the sea to the mainland. One of the most dangerous pollutants for human health is the heavy metal plumbum $(\mathrm{Pb})$. Bioremediation offers a promising alternative method and the potential to reduce the concentration of heavy metals in water. Bioremediation is the application of biological processes to recover a contaminated place by using microorganisms. Biomass of algae Nannochloropsis sp. can be used as bioremediation of heavy metals because it has the ability adsorption caused the active cluster contained therein. In addition, Spirulina sp. thought to have the ability as an agent of bioremediation of heavy metal plumbum $(\mathrm{Pb})$ because the proteins and polysaccharides are high.

Information about uptake ability of heavy metal of plumbum $(\mathrm{Pb})$ by Nannochloropsis sp. and Spirulina sp., in order to know how it compares to the ability of Nannochloropsis sp. and Spirulina sp. in absorbing the content of heavy metal plumbum $(\mathrm{Pb})$. The method used in this study is the experimental method, the test T of SPSS analysis as the experimental design. Treatment given in the form of differences in the concentration of plumbum, which include, treatment A (Nannochloropsis sp. without the addition of plumbum), treatment B (Nannochloropsis sp. $0.9 \mathrm{ppm}$ with plumbum concentrations), treatment C (Spirulina sp. without the addition of plumbum) and treatment D (Spirulina sp. with plumbum concentrations $0.9 \mathrm{ppm}$ ) of each treatment was repeated 5 times. The main parameters measured were real heavy metal plumbum $(\mathrm{Pb})$ in water culture media Nannochloropsis sp. and Spirulinna sp.

The results showed that Nannochloropsis sp. and Spirulina sp. able to absorb the heavy metals plumbum $(\mathrm{Pb})$ so that it can be used as a bioremediation agent, where Spirulina sp. have higher ability in absorbing heavy metals plumbum $(\mathrm{Pb})$ compared with Nannochloropsis sp.
\end{abstract}

Keywords : Nannochloropsis sp., Spirulina sp., heavy metal plumbum (Pb)

\section{Pendahuluan}

Air merupakan sarana utama untuk meningkatkan derajat kesehatan manusia. Air yang tersedia tidak terlepas dari pengaruh pencemaran karena fenomena alam ataupun dari ulah manusia (Darmono, 2001). Air laut merupakan suatu komponen yang berinteraksi dengan lingkungan daratan, dimana buangan limbah dari daratan akan bermuara di laut. Salah satu bahan pencemar yang paling berbahaya bagi kesehatan manusia adalah logam berat (Purnomo, 2009). Timbal (Pb) merupakan logam beracun yang keberadaannya dalam rantai makanan harus selalu diwaspadai karena dapat memberi efek racun terhadap banyak fungsi organ yang terdapat dalam tubuh meskipun hanya sejumlah kecil yang terserap oleh tubuh (Palar, 2008). Bioremediasi menawarkan sebuah metode alternatif yang menjanjikan dan potensial untuk mengurangi konsentrasi logam berat di perairan. Bioremediasi adalah aplikasi dari proses biologis untuk memulihkan suatu tempat yang tercemar dengan menggunakan mikroorganisme. Biomassa alga Nannochloropsis sp. dapat digunakan sebagai bioremediasi logam berat karena memiliki kemampuan adsorbsi yang disebabkan adanya gugus aktif yang terkandung di dalamnya. Selain itu, Spirulina sp. diduga memiliki kemampuan sebagai agen bioremediasi logam berat timbal $(\mathrm{Pb})$ karena kandungan protein dan polisakarida yang tinggi. Berdasarkan rumusan masalah tersebut, tujuan dari penelitian ini adalah : untuk mengetahui kemampuan Nannochloropsis sp. dalam menyerap kandungan logam berat timbal $(\mathrm{Pb})$. Untuk mengetahui kemampuan Spirulina sp. dalam menyerap kandungan logam berat timbal $(\mathrm{Pb})$. Untuk mengetahui perbandingan kemampuan Nannochloropsis sp. dan Spirulina 
sp. dalam menyerap kandungan logam berat timbal $(\mathrm{Pb})$.

Hasil penelitian ini diharapkan dapat memberikan informasi ilmiah mengenai kemampuan Nannochloropsis sp. dan Spirulina sp. dalam menyerap kandungan logam berat timbal $(\mathrm{Pb})$, sehingga dapat dimanfaatkan dalam sistem penanganan limbah yang mengandung timbal $(\mathrm{Pb})$

\section{Metodologi}

Penelitian ini dilakukan di Laboratorium Fakultas Perikanan dan Kelautan, Universitas Airlangga, Surabaya. Pemeriksaan kandungan timbal $(\mathrm{Pb})$ pada air media kultur Nannochloropsis sp. dan Spirulinna sp. dilakukan di Balai Besar Laboratorium Kesehatan, Surabaya. Penelitian ini dilaksanakan pada bulan Mei 2013.

Metode yang digunakan dalam penelitian ini adalah metode eksperimen, yaitu mengadakan percobaan untuk melihat suatu hasil. Perlakuan yang diberikan berupa perbedaan konsentrasi timbal, yang meliputi, perlakuan A (Nannochloropsis sp. tanpa penambahan timbal), perlakuan B (Nannochloropsis sp. dengan konsentrasi timbal 0,9 ppm), perlakuan C (Spirulinna sp. tanpa penambahan timbal) dan perlakuan D (Spirulinna sp. dengan konsentrasi timbal 0,9 ppm).

Pada tahap awal dilakukan sterilisasi alat untuk menghindari adanya kontaminasi oleh mikroorganisme lain. Alat-alat yang disterilkan antara lain tabung Erlemeyer, botol transparan untuk perlakuan dan pipet ukur, dengan menggunakan autoclave pada suhu $121^{\circ} \mathrm{C}$ selama 15 menit. Setelah proses sterilisasi, alat dikeluarkan dari autoclave dan disimpan dalam wadah yang bersih. Untuk botol sampel analisis timbal $(\mathrm{Pb})$ dan akuarium cukup dicuci bersih dengan deterjen, dibilas sampai bersih kemudian direndam dengan HCL $8 \mathrm{~N}$ selama 3 hari dan dikeringkan (Hutagalung, 1995).

Air laut untuk media kultur disterilkan dengan menggunakan kaporit atau klorin 20 ppm minimal selama 24 jam dan dinetralkan dengan larutan natrium thiosulfat $10 \mathrm{ppm}$ untuk menghilangkan sisa klorin dalam air laut.

Larutan timbal yang dibuat yaitu larutan stok larutan timbal $1000 \mathrm{mg} / \mathrm{L}$. Larutan stok digunakan sebagai larutan induk yang dimaksud agar dapat digunakan dalam penelitian dengan cara pengenceran. Cara membuat larutan stok timbal adalah menimbang dengan teliti 1 gram $\mathrm{Pb}\left(\mathrm{NO}_{3}\right)_{2}$ p.a dan melarutkannya ke dalam gelas ukur berisi 100
$\mathrm{mL}$ aquades dengan bantuan pengaduk magnetic agar dapat terlarut sempurna. Kemudian larutan dipindahkan dalam Erlenmeyer $1000 \mathrm{~mL}$ dan ditambah aquades hingga $500 \mathrm{~mL}$ (Gunawati, 2009).

Media kultur yang digunakan dalam penelitian adalah air laut sebanyak $150 \mathrm{~mL}$ dan media Walne sebanyak $2 \mathrm{~mL} / \mathrm{L}$ serta diberi aerasi. Bibit Nannochloropsis sp. dimasukkan dalam botol dengan kepadatan $1 \times 10^{5}$ unit/mL dan Spirulinna sp. dimasukkan dalam botol dengan kepadatan $1 \times 10^{5}$ unit/mL kemudian diaklimatisasi \pm 3 hari pada suhu kamar. Lingkungan kultur yang diharapkan dalam penelitian adalah suhu $30-35^{\circ} \mathrm{C}$, salinitas $30-35$ ppt, $\mathrm{pH}$ 8-9,5 yang merupakan lingkungan kultur terbaik Nannochloropsis sp. dan Spirulinna sp. Photoperiod 12 jam dalam keadaan terang dan 12 jam dalam keadaan gelap.

Perhitungan jumlah bibit Nannochloropsis sp. dan Spirulinna sp. untuk kultur menggunakan rumus :

$$
V 1=\frac{W_{2 x} x V_{1}}{N 1}
$$

Keterangan :

V1 : Volume bibit untuk penebaran awal $(\mathrm{mL})$

N1 : Kepadatan bibit / stock Nannochloropsis sp. dan Spirulinna sp. (unit/mL)

V2 : Volume media kultur yang dikehendaki (mL)

N2 : Kepadatan Nannochloropsis sp. dan Spirulinna sp. yang dikehendaki (unit/mL)

Nannochloropsis sp. dan Spirulinna sp. yang akan digunakan untuk penelitian kemudian dimasukkan ke dalam masing-masing 10 botol transparan yang berisi air media sebanyak 130 $\mathrm{mL}$ dengan bibit Nannochloropsis sp. dimasukkan dalam botol dengan kepadatan $1 \times 10^{5}$ unit $/ \mathrm{mL}$ dan Spirulinna sp. dengan kepadatan $1 \times 10^{5} \quad$ unit $/ \mathrm{mL}$. Setelah teraklimatisasi masing-masing biakan Nannochloropsis sp. dan Spirulinna sp. diberi perlakuan timbal $(\mathrm{Pb})$ dengan konsentrasi $0 \mathrm{ppm}$ dan 0,9 ppm dengan 5 kali ulangan. Pada perlakuan 0 ppm ditambahkan aquades $1,17 \mathrm{~mL}$ sebagai pengganti timbal $(\mathrm{Pb})$ dan pada perlakuan $0,9 \mathrm{ppm}$ ditambahkan larutan timbal $(\mathrm{Pb})$ sebanyak 1,17. Larutan biakan kemudian diinkubasi pada suhu $\pm 33^{\circ} \mathrm{C}$ selama 1 hari dan diberi cahaya selama 12 jam sehari dengan lampu neon 40 watt yang diletakkan diatas botol dengan jarak menyesuaikan. 
Pengambilan data kemampuan timbal $(\mathrm{Pb})$ oleh Nannochloropsis sp. dan Spirulinna sp. dilakukan pada akhir perlakuan yaitu pada hari ke-1, sampel disaring dengan kertas 0,45 $\mu \mathrm{m}$ untuk memisahkan Nannochloropsis sp. dan Spirulinna sp. dengan air media.

Pengukuran konsentrasi timbal $(\mathrm{Pb})$ pada air media diuji dengan AAS untuk mengetahui konsentrasi timbal $(\mathrm{Pb})$ yang tersisa pada media kultur Nannochloropsis sp. dan Spirulinna sp. Hasil pengukuran konsentrasi timbal $(\mathrm{Pb})$ yang tersisa pada media pemeliharaan plankton pada akhir penelitian menunjukkan sisa timbal $(\mathrm{Pb})$ yang tidak terserap oleh Nannochloropsis sp. dan Spirulinna sp. Standart pengujian AAS yang digunakan yaitu SNI 6989.8 - 2009. Hasilnya disajikan dalam bentuk presentase untuk mengetahui kemampuan Nannochloropsis sp. dan Spirulinna sp. dalam bioremediasi timbal $(\mathrm{Pb})$ pada konsentrasi 0,9 ppm.

Analisis data yang digunakan dalam penelitian adalah analisis secara statistik dan deskriptif. Analisis yang digunakan untuk menjawab rumusan masalah adalah dengan uji $\mathrm{T}$ yang dilakukan pada program SPSS 16 for windows. Analisis data deskriptif digunakan untuk mengetahui kapasitas konsentrasi logam berat timbal $(\mathrm{Pb})$ yang mampu diserap oleh Nannochloropsis sp. dan Spirulina sp.

\section{Hasil dan Pembahasan}

Hasil analisa kandungan logam berat timbal $(\mathrm{Pb})$ dalam air media kultur Nannochloropsis sp. dan Spirulina sp. selama penelitian menunjukkan terjadinya penurunan. Hasil analisa rata-rata kandungan logam berat timbal $(\mathrm{Pb})$ dalam air media kultur dapat dilihat pada Tabel 1. Terhadap air media kultur tanpa penambahan logam berat timbal $(\mathrm{Pb})$, juga dilakukan analisa kandungan logam berat timbal $(\mathrm{Pb})$ dan diketahui bahwa pada media tersebut juga terdapat kandungan logam berat timbal $(\mathrm{Pb})$.

Analisa data kandungan logam berat timbal $(\mathrm{Pb})$ diuji secara statistik menggunakan SPSS uji T, masing-masing terhadap : 1) Kandungan logam berat timbal $(\mathrm{Pb})$ air media kultur Nannochloropsis sp. pada awal dan akhir penelitian, 2) Kandungan logam berat timbal $(\mathrm{Pb})$ air media kultur Spirulina sp. pada awal dan akhir penelitian, 3) Persentase penurunan kandungan logam berat timbal $(\mathrm{Pb})$ air media kultur Nannochloropsis sp. dan Spirulina sp. pada akhir penelitian.

Tabel 1. Rata-rata kandungan logam berat timbal $(\mathrm{Pb})$ dalam air media kultur Nannochloropsis sp. dan Spirulina sp.

\begin{tabular}{|c|r|r|r|r|}
\hline \multirow{2}{*}{$\begin{array}{c}\text { Hari } \\
\text { ke- }\end{array}$} & $\begin{array}{c}\text { Nannochloropsis sp. } \\
\text { Pb 0 ppm (A) }\end{array}$ & $\begin{array}{c}\text { Nannochloropsis sp. } \\
\text { Pb 0,9 ppm (B) }\end{array}$ & $\begin{array}{c}\text { Spirulina sp. } \\
\text { Pb 0 ppm } \\
\text { (C) }\end{array}$ & $\begin{array}{c}\text { Spirulina } \text { sp. } \\
\text { Pb 0,9 ppm } \\
\text { (D) }\end{array}$ \\
\hline 0 (awal) & 0,0130 & 0,9006 & 0,0380 & 0,8977 \\
\hline 1 (akhir) & 0,0108 & 0,7973 & 0,0220 & 0,7850 \\
\hline $\begin{array}{c}\text { Selisih } \\
\text { kandungan } \mathrm{Pb}\end{array}$ & 0,0021 & 0,1032 & 0,0159 & 0,1126 \\
\hline $\begin{array}{c}\text { Persentase } \\
\text { penurunan (\%) }\end{array}$ & 16,46 & 11,46 & 42 & 12,54 \\
\hline
\end{tabular}

Tabel 2. Analisa kandungan logam berat timbal $(\mathrm{Pb})$ dalam air media kultur Nannochloropsis sp. dengan konsentrasi 0 ppm

\begin{tabular}{|c|c|c|c|c|}
\hline \multirow{3}{*}{ Ulangan } & \multicolumn{4}{|c|}{ Nannochloropsis sp. } \\
\hline & \multicolumn{4}{|c|}{ Konsentrasi $\mathrm{Pb} 0$ ppm (A) } \\
\hline & Awal (0 hari) & Akhir (1 hari) & (Awal-Akhir) & Persentase $(\%)$ \\
\hline 1 & 0.013 & 0.0114 & 0.0016 & 12.30769231 \\
\hline 2 & 0.013 & 0.0102 & 0.0028 & 21.53846154 \\
\hline 3 & 0.013 & 0.0107 & 0.0023 & 17.69230769 \\
\hline 4 & 0.013 & 0.0122 & 0.0008 & 6.153846154 \\
\hline \multirow[t]{3}{*}{5} & 0.013 & 0.0098 & 0.0032 & 24.61538462 \\
\hline & \multirow{2}{*}{\multicolumn{2}{|c|}{$\begin{array}{c}\text { Total } \\
\text { Rata-rata }\end{array}$}} & 0.0107 & 82.30769231 \\
\hline & & & 0.00214 & 16.46153846 \\
\hline
\end{tabular}


Tabel 3. Analisa kandungan logam berat timbal $(\mathrm{Pb})$ dalam air media kultur Nannochloropsis sp. dengan konsentrasi 0,9 ppm

\begin{tabular}{|c|c|c|c|c|}
\hline \multirow{3}{*}{ Ulangan } & \multicolumn{4}{|c|}{ Nannochloropsis sp. } \\
\hline & \multicolumn{4}{|c|}{ Konsentrasi $\mathrm{Pb} 0,9$ ppm (B) } \\
\hline & Awal (0 hari) & Akhir (1 hari) & (Awal-Akhir) & Persentase $(\%)$ \\
\hline 1 & 0.9006 & 0.8063 & 0.0943 & 10.47079725 \\
\hline 2 & 0.9006 & 0.7999 & 0.1007 & 11.1814346 \\
\hline 3 & 0.9006 & 0.7483 & 0.1523 & 16.91094826 \\
\hline 4 & 0.9006 & 0.8606 & 0.04 & 4.441483455 \\
\hline \multirow[t]{3}{*}{5} & 0.9006 & 0.7717 & 0.1289 & 14.31268044 \\
\hline & \multirow{2}{*}{\multicolumn{2}{|c|}{$\begin{array}{c}\text { Total } \\
\text { Rata-rata }\end{array}$}} & 0.5162 & 57.31734399 \\
\hline & & & 0.10324 & 11.4634688 \\
\hline
\end{tabular}

Tabel 4. Analisa kandungan logam berat timbal $(\mathrm{Pb})$ dalam air media kultur Spirulina sp. dengan konsentrasi 0 ppm

\begin{tabular}{|c|c|c|c|c|}
\hline \multirow{3}{*}{ Ulangan } & \multicolumn{4}{|c|}{ Spirulina sp. } \\
\hline & \multicolumn{4}{|c|}{ Konsentrasi $\mathrm{Pb} 0$ ppm ( C ) } \\
\hline & Awal (0 hari) & Akhir (1 hari) & (Awal-Akhir) & Persentase $(\%)$ \\
\hline 1 & 0.038 & 0.0214 & 0.0166 & 43.68421053 \\
\hline 2 & 0.038 & 0.0276 & 0.0104 & 27.36842105 \\
\hline 3 & 0.038 & 0.0104 & 0.0276 & 72.63157895 \\
\hline 4 & 0.038 & 0.0207 & 0.0173 & 45.52631579 \\
\hline \multirow[t]{3}{*}{5} & 0.038 & 0.0301 & 0.0079 & 20.78947368 \\
\hline & \multirow{2}{*}{\multicolumn{2}{|c|}{$\begin{array}{c}\text { Total } \\
\text { Rata-rata }\end{array}$}} & 0.0798 & 210 \\
\hline & & & 0.01596 & 42 \\
\hline
\end{tabular}

Kandungan logam berat timbal $(\mathrm{Pb})$ dalam air media kultur Nannochloropsis sp. dengan konsentrasi $0 \mathrm{ppm}$, dapat dilihat pada tabel 2. Sedangkan untuk kandungan logam berat timbal $(\mathrm{Pb})$ dalam air media kultur Nannochloropsis sp. dengan konsentrasi 0,9 ppm, dapat dilihat pada tabel 3 .

Hasil uji $\mathrm{T}$ kandungan logam berat timbal $(\mathrm{Pb})$ air media kultur Nannochloropsis sp. dengan $\mathrm{Pb} 0$ ppm pada awal dan akhir penelitian diketahui bahwa terdapat perbedaan kandungan logam berat timbal $(\mathrm{Pb})$ pada awal dan akhir penelitian, dimana nilai sig $(0,008)<$ 0,05. Sedangkan dengan $\mathrm{Pb} 0,9$ ppm pada awal dan akhir diketahui bahwa terdapat perbedaan kandungan logam berat timbal $(\mathrm{Pb})$ pada awal dan akhir penelitian, dimana nilai sig $(0,005)<$ 0,05 .

Kandungan logam berat timbal $(\mathrm{Pb})$ dalam air media kultur Spirulina sp. dengan konsentrasi 0 ppm, dapat dilihat pada tabel 4 . Sedangkan untuk kandungan logam berat timbal $(\mathrm{Pb})$ dalam air media kultur Spirulina sp. dengan konsentrasi 0,9 ppm, dapat dilihat pada tabel 5 .

Hasil uji $\mathrm{T}$ kandungan logam berat timbal $(\mathrm{Pb})$ air media kultur Spirulina sp. dengan $\mathrm{Pb} 0$ ppm pada awal dan akhir penelitian diketahui bahwa terdapat perbedaan kandungan logam berat timbal $(\mathrm{Pb})$ pada awal dan akhir penelitian, dimana nilai sig $(0,01)<0,05$. Sedangkan dengan $\mathrm{Pb} 0,9$ ppm pada awal dan akhir penelitian diketahui bahwa terdapat perbedaan kandungan logam berat timbal $(\mathrm{Pb})$ pada awal dan akhir penelitian, dimana nilai sig $(0,00)<0,05$.

Perbandingan persentase penurunan kandungan logam berat timbal $(\mathrm{Pb})$ pada air media kultur Nannochloropsis sp. dan Spirulina sp. dengan konsentrasi 0 ppm dapat dilihat pada gambar 1. Sedangkan untuk konsentrasi 0,9 ppm dapat dilihat pada gambar 2 .

Hasil analisa SPSS uji $\mathrm{T}$ pada data persentase penurunan kandungan logam berat timbal $(\mathrm{Pb})$ pada air media kultur Nannochloropsis sp. dan Spirulina sp. dengan $\mathrm{Pb} 0$ ppm pada akhir penelitian menunjukkan 
Tabel 5. Analisa kandungan logam berat timbal $(\mathrm{Pb})$ dalam air media kultur Spirulina sp. dengan konsentrasi $0,9 \mathrm{ppm}$

\begin{tabular}{|c|c|c|c|c|}
\hline \multirow{3}{*}{ Ulangan } & \multicolumn{4}{|c|}{ Spirulina sp. } \\
\hline & \multicolumn{4}{|c|}{ Konsentrasi $\mathrm{Pb} 0,9$ ppm (D) } \\
\hline & Awal (0 hari) & Akhir (1 hari) & (Awal-Akhir) & Persentase $(\%)$ \\
\hline 1 & 0.8977 & 0.7216 & 0.1761 & 19.61679849 \\
\hline 2 & 0.8977 & 0.8403 & 0.0574 & 6.394118302 \\
\hline 3 & 0.8977 & 0.7108 & 0.1869 & 20.81987301 \\
\hline 4 & 0.8977 & 0.7911 & 0.1066 & 11.87479113 \\
\hline \multirow[t]{3}{*}{5} & 0.8977 & 0.8614 & 0.0363 & 4.043667149 \\
\hline & \multirow{2}{*}{\multicolumn{2}{|c|}{$\begin{array}{c}\text { Total } \\
\text { Rata-rata }\end{array}$}} & 0.5633 & 62.74924808 \\
\hline & & & 0.11266 & 12.54984962 \\
\hline
\end{tabular}

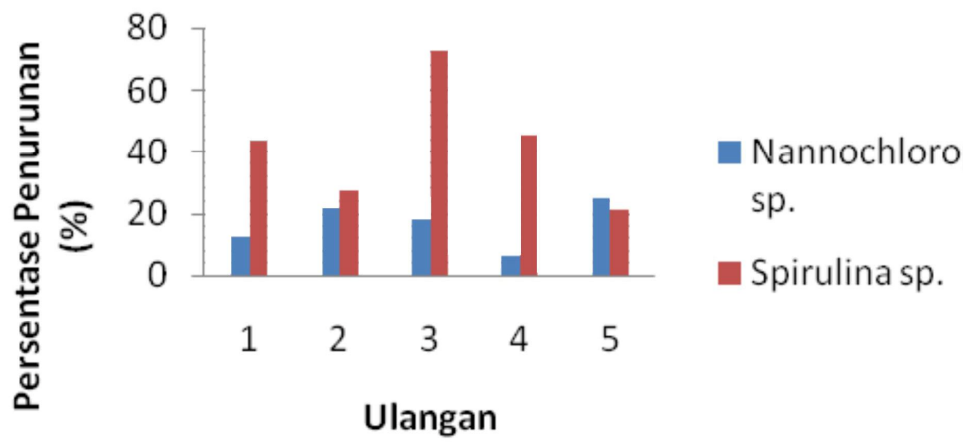

Gambar 1. Perbandingan persentase penurunan kandungan logam berat timbal $(\mathrm{Pb})$ pada air media kultur Nannochloropsis sp. dan Spirulina sp. (0 ppm)

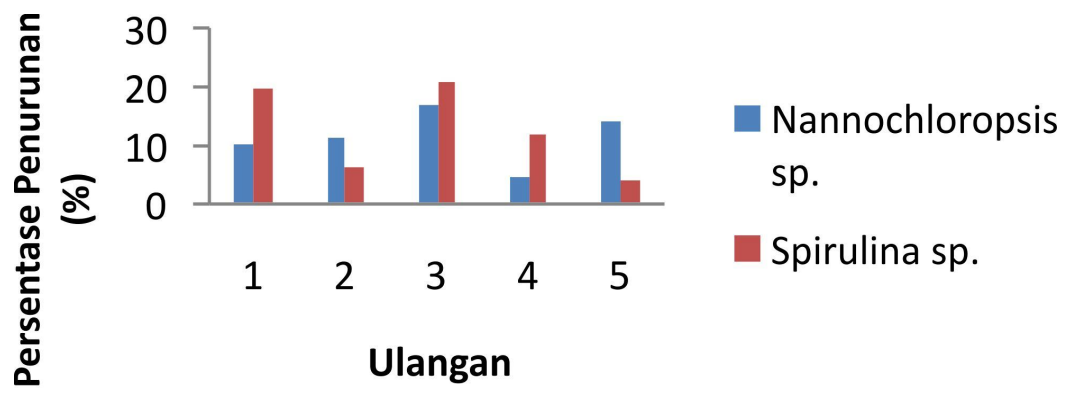

Gambar 2. Perbandingan persentase penurunan kandungan logam berat timbal $(\mathrm{Pb})$ pada air media kultur Nannochloropsis sp. dan Spirulina sp. (0,9 ppm)

adanya perbedaan antara kandungan logam berat timbal $(\mathrm{Pb})$ pada air media kultur Nannochloropsis sp. dan kandungan logam berat timbal $(\mathrm{Pb})$ pada air media kultur Spirulina sp., dimana nilai sig $(0,029)<0,05$. Sedangkan, dengan $\mathrm{Pb}$ 0,9 ppm menunjukkan tidak adanya perbedaan antara kandungan logam berat timbal $(\mathrm{Pb})$ pada air media kultur
Nannochloropsis sp. dan kandungan logam berat timbal $(\mathrm{Pb})$ pada air media kultur Spirulina sp., dimana nilai sig $(0,792)>0,05$.

Hasil pengukuran kandungan logam berat timbal $(\mathrm{Pb})$ pada air media kultur Nannochloropsis sp. dan Spirulina sp. tanpa penambahan logam berat timbal $(\mathrm{Pb})$, ternyata masih terdapat kandungan logam berat timbal 
$(\mathrm{Pb})$ di dalamnya. Diduga kandungan logam berat tersebut berasal dari air media kultur yang sebelumnya telah mengandung logam berat timbal $(\mathrm{Pb})$. Air laut alami yang dimungkinkan telah mengandung logam berat timbal $(\mathrm{Pb})$ dapat berasal dari residu bahan bakar yang digunakan kapal-kapal atau kegiatan industri yang membuang limbahnya ke sungai-sungai dan bermuara di laut (Yanney, 1990).

Hasil uji T terhadap kandungan logam berat timbal $(\mathrm{Pb})$ pada air media kultur Nannochloropsis sp. dan Spirulina sp. baik tanpa penambahan $\mathrm{Pb}$ maupun dengan penambahan $\mathrm{Pb}$ menunjukkan adanya perbedaan kandungan awal dan akhir penelitian, dimana nilai sig $<0,05$. Hal ini menunjukkan bahwa Nannochloropsis sp. dan Spirulina sp. memiliki kemampuan untuk menyerap logam berat logam timbal $(\mathrm{Pb})$ sehingga dapat digunakan sebagai agen bioremediasi logam berat timbal $(\mathrm{Pb})$.

Hasil uji $\mathrm{T}$ terhadap persentase penurunan kandungan logam berat timbal $(\mathrm{Pb})$ pada air media kultur Nannochloropsis sp. dan Spirulina sp. tanpa penambahan logam berat timbal $(\mathrm{Pb})$ menunjukkan hasil berbeda. Sedangkan dengan penambahan logam berat timbal $(\mathrm{Pb})$ menunjukkan hasil tidak berbeda secara statistik (uji T). Namun nilai persentase penurunan kandungan logam berat timbal $(\mathrm{Pb})$ Spirulina sp. lebih besar dibandingkan Nannochloropsis sp. Hal tersebut bisa terjadi karena diduga Spirulina sp. memiliki gugus fungsi lebih banyak dibandingkan Nannochloropsis sp. sehingga penyerapan terhadap logam berat timbal $(\mathrm{Pb})$ menunjukkan hasil yang berbeda.

Nannochloropsis sp. merupakan jenis alga hijau bersel satu yang dapat dimanfaatkan untuk mengadsorpsi ion-ion logam. Menurut Putra (2007), kemampuan adsorpsinya cukup tinggi karena di dalam Nannochloropsis sp. terdapat gugus fungsi amina, amida dan karboksilat yang berikatan dengan ion logam. Menurut Babadzhanov (2004), Spirulina sp. memiliki kandungan protein yang sangat tinggi dari $55 \%$ hingga $77 \%$. Dalam proses bioremediasi, protein dan polisakarida memegang peranan penting untuk mengikat logam berat karena ion logam berat akan mengadakan ikatan dengan gugus karboksil dari protein dan gugus hidroksil dari polisakarida (Gupta et al., 2000). Mekanismenya adalah gugus karboksil dan hidroksil dari dinding sel berperan sebagai anion yang akan mengikat kation logam berat.

Gugus fungsi yang dimiliki oleh Nannochloropsis sp. dan Spirulina sp. tersebut dapat melakukan pengikatan dengan ion logam disebabkan karena adanya reaksi antara muatan positif ion logam berat timbal $(\mathrm{Pb})$, sehingga terjadi pengikatan ion akibat dari perbedaan muatan tersebut. Proses pengikatan ion logam berat dengan gugus fungsi sulfat adalah

$$
\begin{aligned}
& \mathrm{SO}_{4}^{2-}+\mathrm{Pb}^{2+} \rightarrow \mathrm{Pb}\left(\mathrm{SO}_{4}\right) \\
& \text { Pemanfaatan }
\end{aligned}
$$

Nannochloropsis sp. dan Spirulina sp. sebagai agen bioremediasi memiliki kelebihan. Nannochloropsis sp. tidak memiliki lapisan lendir pada permukaan tubuhnya sehingga tidak ada proteksi khusus untuk terserapnya logam berat timbal $(\mathrm{Pb})$ ke dalam tubuh Nannochloropsis sp. Sedangkan Spirulina sp. memiliki kemampuan adaptasi yang cukup tinggi sehingga mudah ditumbuhkan.

\section{Kesimpulan}

Kesimpulan yang diperoleh dari penelitian ini adalah terdapat perbedaan kemampuan penyerapan logam berat timbal (Pb) antara Nannochloropsis sp. dan Spirulina sp., dimana persentase penurunan kandungan logam berat timbal $(\mathrm{Pb})$ dalam air media kultur Spirulina sp. lebih tinggi dibandingkan dengan Nannochloropsis sp.

Mikroalga Nannochloropsis sp. dan Spirulina sp. dapat digunakan sebagai agen bioremediasi logam berat timbal $(\mathrm{Pb})$, sehingga diharapkan dapat dimanfaatkan untuk menurunkan limbah yang mengandung logam berat timbal $(\mathrm{Pb})$ pada instalasi pengolahan limbah sebelum dibuang ke perairan sehingga perairan tetap lestari dan dapat dimanfaatkan secara berkelanjutan.

\section{Daftar Pustaka}

Babadzhanov, A.S. 2004. Chemical Composition of Spirulina Platensis Cultivated in Uzbekistan. Chemistry of Natural Compounds. Uzbekistan

Darmono. 2001. Lingkungan Hidup dan Pencemaran. UI Press. Jakarta.

Gunawati, W. D. 2009. Bioremoval oleh Spirulina plantesis. Skripsi. Fakultas Sains dan Teknologi. Universitas Airlangga. Surabaya

Gupta, R., Ahuja, P., Khan, S., Saxena, RK., and Mohapatra, H. 2000. Microbial Biosorbents: Meeting Challenges of Heavy Metal Pollution in Aqueous Solution. Current Science, (78) 967973

Hutagalung, H. 1995. Heavy Metals Content in Sediment in Jakarta Bay, Indonesia. Dalam : Asean Criteria and Monitoring. Advance in Marine Environmental Management and 
Human Health Protection (Watson D, KS Wong and Vigers Eds) Asean Canada CPMS II. Proceeding of Asean Canada Midterm Technical Review Conference on Marine Science, Singapore 24-28 Oktober 1994. Hal: 273-275

Palar, H. 2008. Pencemaran dan Toksikologi Logam Berat. Rineka Cipta. Jakarta

Purnomo, D. 2009. Logam Berat Sebagai Penyumbang Pencemaran Air Laut. Diarsip oleh Lingkungan Hidup.
Putra, S.E. 2003. Alga Sebagai Bioindikator dan Biosorben Logam Berat (Bagian II:Biosorben). Jurusan Kimia FMIPA Universitas Lampung. [Online]. Tersedia : http://www.chem-is-try.org. (7 Maret 2013)

Yanney, E. 1990. Ekologi Tropika. Penerbit ITB. Bandung. 